\title{
PERAN AIESEC LOCAL COMMITTEE (LC) BANDUNG DALAM MENDUKUNG PENCAPAIAN SUSTAINABLE DEVELOPMENT GOALS (SDGS)
}

\author{
Claudia Karina Putri \\ Program Studi Ilmu Hubungan Internasional, Fakultas Ilmu Sosial dan Ilmu Politik Universitas Komputer \\ Indonesia Jalan Dipatiukur No. 112-116, Bandung 40132 Indonesia
}

Email: claudiakarinaputri@gmail.com

\begin{abstract}
As an International Non-Governmental Organization, AIESEC Bandung is supporting the achievement of SDGs. There are various activities of AIESEC Bandung, both internship programs and social projects that have an impact on achieving SDGs. In addition, AIESEC Bandung has carried out internships and social projects long before the SDGs were issued. After the SDGs were issued, AIESEC Bandung then included SDGs goals and targets relevant to the AIESEC Bandung social project. Based on the results of interviews and literature studies, it can be seen that there are various social projects in AIESEC Bandung that help achieve SDGs, such as the Sampurasun, I Green, Social Entrepreneur, Impacting, Malala and I Care for Disabled projects. Both project participants and project partners feel the positive results of these social projects. The activities of AIESEC Bandung which continue to take place every year also make this activity sustainable. Even so, there are still many improvements that must be improved by AIESEC Bandung to support the achievement of SDGs, such as social project sustainability issues, difficulties in finding partners and the absence of cooperation with the government.
\end{abstract}

Keywords: AIESEC, Sustainable Development Goals, Social Projects, International NonGovernmental Organizations

\begin{abstract}
ABSTRAK
Sebagai sebuah Organisasi Internasional Non-Pemerintah, AIESEC Bandung memberikan dukungan terhadap pencapaian SDGs. Terdapat berbagai kegiatan AIESEC Bandung baik itu program magang maupun proyek sosial memiliki dampak dalam pencapaian SDGs. Selain itu, AIESEC Bandung sudah menjalankan kegiatan magang dan proyek sosial jauh sebelum SDGs dikeluarkan. Setelah SDGs dikeluarkan, AIESEC Bandung kemudian memasukan tujuan dan target SDGs yang relevan dengan proyek sosial AIESEC Bandung. Berdasarkan hasil wawancara dan studi pustaka dapat dilihat bahwa terdapat berbagai proyek sosial di AIESEC Bandung yang membantu pencapaian SDGs, seperti proyek Sampurasun, I Green, Social Enterpreneur, Impacting, Malala dan I Care for Disabled. Baik peserta proyek maupun partner proyek merasakan hasil positif dari proyek-proyek sosial tersebut. Kegiatankegiatan AIESEC Bandung yang terus berlangsung setiap tahunnya juga menjadikan kegiartan ini sustainable. Meski begitu masih banyak perbaikan yang harus ditingkatkan oleh AIESEC Bandung untuk mendukung pencapaian SDGs, seperti permasalahan kesinambungan proyek sosial, kesulitan mencari partner maupun tidak adanya kerjasama dengan pemerintah.
\end{abstract}

Kata Kunci : AIESEC, Sustainable Development Goals, Proyek Sosial, Organisasi Internasional 


\section{Pendahuluan}

\subsection{Latar Belakang}

Sejak berakhirnya perang dunia kedua, hubungan internasional secara perlahan berubah. Banyak isu-isu baru yang awalnya bukan merupakan bagian dalam hubungan internasional, menjadi isu hubungan internasional. Isu-isu tersebut seringkali disebut sebagai isu non tradisional. Salah satu dari isu non tradisional yang hingga saat ini sering menjadi perbincangan merupakan isu lingkungan hidup. Pasca perang dunia kedua, banyak negara yang mengalami kerugian baik finansial, sumber daya manusia dan sumber daya alam. Perang yang berlangsung selama bertahun-tahun menyebabkan banyak kerusakan terutama pada lingkungan hidup. Warga dunia pun sadar bahwa lingkungan hidup merupakan isu yang penting karena mengangkut hajat hidup setiap orang.

Untuk menangani berbagai permasalahan di dunia, PBB menciptakan Millenium Development Goals (MDGs) yang berisikan 8 capaian pembangunan nasional yang harus di capai oleh setiap negara terutama negara berkembang. MDGs disahkan pada bulan September tahun 2000 dan disepakati untuk tercapai pada tahun 2015. Kemudian, pada tanggal 2 Agustus 2015, PBB dalam rapat umumnya mengumumkan resolusi A/RES/70/1 dengan tema 'Transforming Our World: the 2030 Agenda for Suistainable Development'. Resolusi ini berisi 17 Tujuan Pembangunan Berkelanjutan (Sustainable Development Goals atau SDGs) dengan 169 capaian yang disahkan pada tanggal 25 September 2015. SDGs dibuat dengan upaya meneruskan dan memantapkan capaian-capaian

MDGs (https://www.theguardian.com/globaldevelopm ent $/ 2015 /$ jan$/ 19 /$ sustainabledevelopment-goalsunited-nations diakses pada 4 Januari 2018).

SDGs menjadi penting karena untuk menciptakan pembangunan yang stabil dan berkelanjutan diperlukan perbangunan dan perbaikan di berbagai sektor mulai dari kesehatan hingga ekonomi dan SDGs mengandung setiap poin pembangunan yang dibutuhkan setiap negara. Dalam hal ini, dapat disimpulkan bahwa SDGs merupakan upaya perbaikan yang holistik dan mampu menyentuh setiap bidang.

Setiap negara yang menjadi anggota $\mathrm{PBB}$, terutama negara-negara yang ikut merumuskan capaian-capaian dalam SDGs wajib untuk berusaha mencapai setiap capaian SDGs. Meski begitu, SDGs difokuskan untuk 
Vol. 2 No.1 April 2019

membantu pengembangan di negara berkembang karena negara-negara maju berpendapat bahwa ketimpangan sosial, kemiskinan dan kurangnya pendidikan di negara berkembanglah dapat mempengaruhi ekosistem dunia.

Selain aktor-aktor pemerintahan, terdapat pula aktor non pemerintah yang mendukung tercapainya SDGs, seperti Organisasi Internasional non-pemerintah (INGO), Lembaga Swadaya Masyarakat (LSM), hingga aktor individual. Salah satu aktor nonpemerintah yang ikut mendukung tercapainya SDGs adalah organisasi internasional nonpemerintah bernama AIESEC.

Asal mula nama AIESEC berasal dari Association Internationale des Etudiants en Sciences Economiques et Commerciales yang artinya Asosiasi Mahasiswa dibidang ekonomi dan bisnis. Seiring berkembangnya jaman, anggota AIESEC tidak hanya berasal dari bidang ekonomi dan bisnis. Tujuan AIESEC juga berubah seiring waktu. Oleh karena itu AIESEC tidak lagi menggunakan kepanjangan dari kata AIESEC (Dokumen AIESEC Blue Book Brand Toolkit, 2016:9).

AIESEC adalah organisasi pemuda global, independen, non pemerintah dan nirlaba yang didirikan pada tahun 1948 oleh sekelompok orang muda Eropa yang berasal dari negara-negara yang berbeda. Dasar-dasar AIESEC dibentuk oleh iklim sosial, politik dan ekonomi pada waktu itu. Pada awalnya AIESEC bertujuan untuk menciptakan jaringan di seluruh dunia, yang bercita-cita untuk Perdamaian dan Pemenuhan Potensi Manusia, sehingga orangorang muda di seluruh dunia dapat memiliki kesempatan untuk mengembangkan kepribadian mereka dalam iklim yang damai, memberikan versi terbaik dari diri mereka sendiri (http://aiesec.at/tag/aiesec-history/ diakses pada 22 Mei 2018).

AIESEC memiliki kantor cabang di Bandung, Indonesia. AIESEC di Bandung berusaha membantu kota Bandung dengan berkontribusi mengadakan projek sosial yang fokus di bidang tertentu untuk mengembangkan potensi sumber daya yang lebih baik seperti lingkungan, budaya, dan kewirausahaan dan memberikan kesempatan bagi anggota AIESEC Bandung untuk melakukan program pertukaran pemuda melalui program volunteering di luar negri (berita.upi.edu/muda-potensial-danberpengaruh/ diakses pada 14 April 2018).

\subsection{Rumusan Masalah}

\subsubsection{Rumusan Masalah Mayor}

Berdasarkan masalah yang telah dijabarkan diatas, maka peneliti ingin mengutarakan Bagaimana Bagaimana peran AIESEC LC Bandung dalam mendukung pencapaian SDGs?

\subsubsection{Rumusan Masalah Minor}

1. Apa saja program-program yang dilakukan oleh AIESEC Bandung untuk mendukung pencapaian SDGs?

2. Apa saja kendala yang dihadapi oleh AIESEC Bandung dalam mendukung pencapaian SDGs?

3. Bagaimana Pencapaian AIESEC Bandung dalam mendukung pencapaian SDGs?

\subsection{Maksud dan Tujuan}

Maksud dan tujuan dari penelitian ini adalah untuk melihat peran AIESEC Bandung dalam mengupayakan Sustainable Development Goals melalui berbagai kegiatan AIESEC Bandung. Dan tujuan penelitian ini adalah untuk mengetahui program-program AIESEC Bandung dalam membantu pencapaian SDGs, untuk mengetahui kendala apa saja yang dihadapi dalam membantu pencapaian SDGs dan untuk mengetahui pencapaian AIESEC Bandung dalam membantu pencapaian SDGs.

\section{Kajian Pustaka dan Kerangka Pemikiran}

\subsection{Hubungan Internasional}

Hubungan internasional adalah disiplin ilmu yang melibatkan sejumlah besar fakta tentang dunia. Tetapi seperti telah disebutkan sebelumnya, fakta-fakta ini hanya akan menjadi lebih bermakna dan relevan ketika tersedia suatu kerangka berpikir dalam bentuk teori sebagai tempat bagi fakta-fakta tersebut untuk dideskripsikan, dianalisis dan bahkan 


\section{Vol. 2 No.1 April 2019}

memperhitungkan sesuatu yang akan terjadi ke depan. Pada tingkat negara fungsi aktor yang umumnya hanya dijalankan oleh lembaga atau badan- badan yang dibentuk khusus contohnya lembaga diplomatik resmi, mulai bergeser peranannya akibat arus globalisasi. Batas-batas kedaulatan negara menjadi semakin relatif maknanya sehingga gejala ini pun seringkali digambarkan sebagai dunia tanpa batas (Dugis, 2016:10).

Hubungan Internasional dapat dilaksanakan melalui banyak jalur di samping jalur pemerintah. Sebagai aktor dalam politik global, negara tidak selalu bertindak sebagai aktor yang unitary dan kelompok-kelompok yang ada di dalamnya tidak selalu bertindak secara koheren. Selain negara, ada banyak aktor lain seperti perusahaan multinasional, organisasi internasional dan sebagainya (Jemadu, 2008:46).

\subsection{Organisasi Internasional}

Organisasi Internasional dapat di definisikan sebagai sebuah struktur formal yang berkesinambungan, yang pembentukannya didasarkan pada perjanjian antar anggotanya yang berasal dari dua atau lebih negara berdaulat untuk mencapai tujuan bersama dari para anggotannya (Archer, 2001:35).

Berdasarkan Konvensi Wina unsur-unsur pendirian organisasi internasional antara lain:

1. Dibuat oleh negara sebagai para pihak (contracting state).

2. Berdasarkan perjanjian tertulis dalam satu, dua atau lebih instrumen.

3. Memiliki tujuan tertentu.

4. Dilengkapi dengan struktur organisasi internasional yang jelas berdasarkan hukum internasional (legal.un.org/avl/ha/vcltsio/vcltsio.html diakses pada 3 April 2018).

Menurut Menurut Thomas L. Karnes (1961) dalam "Pendirian dan Pembubaran Organisasi Internasional" oleh Dewi Triwahyuni (2010), terdapat beberapa syarat dalam mendirikan organisasi internasional, seperti:

1. Harus ada perwakilan resmi pemerintah. Karena negara yang menerapkan sistem pemilihan umum secara demokratis tidak mungkin mentransfer kekuasaannya secara terpisah dari garis diktatorianisme atau kepemerintahan. Selain itu, tidak banyak pemerintahan yang akan menerima terjadinya komunikasi secara langsung antara organisasi internasional dengan warga negaranya.

2. Konsentrasi negara harus mengacu pada upaya mengembangkan struktur pemerintahan. Sehingga organisasi supranasional dapat berfungsi bagi negara.

3. Nasionalisme tidak boleh menjadi ciri utama dari setiap negara partisipan.

4. Negara-negara anggota harus memiliki kepentingan bersama. Hal ini juga menjadi faktor yang menentukan besarnya respek negara apabila dilihat dari keuntungan yang akan didapatkan dalam organisasi. (Triwahyuni, 2010)

\subsubsection{Organisasi Non-Pemerintah Internasional}

Non-Government Organization (NGO) yang jika diterjemahkan ke dalam bahasa Indonesia berarti Organisasi Non Pemerintah atau lebih dikenal dengan sebutan Lembaga Swadaya Masyarakat (LSM). Ririen (2009) NGO adalah suatu kelompok atau asosiasi nirlaba yang beraktifitas di luar struktur politik yang terinstitusionalisasi. Pencapaian hal-hal yang menjadi minat atau tujuan anggotanya diupayakan melalui lobi, persuasi, atau aksi langsung.

Ririen (2009), NGO biasanya memperoleh sebagian pendanaannya dari sumber-sumber swasta. Semakin baik kinerja dan produktifitas yang dihasilkan oleh sebuah NGO sehingga manfaat yang dirasakan oleh masyarakat semakin besar, maka dana yang akan mengalir ke NGO tersebut tentunya akan semakin besar pula. Hal itu menunjukkan bahwa kepercayaan dari pihak-pihak donatur untuk mendanai sebuah NGO tentu saja semakin besar. Berdasarkan teori-teori diatas dapat disimpulkan bahwa AIESEC merupakan NGO Operasional karena kelompok ini menggerakkan sumber daya dalam bentuk keuangan, material atau tenaga relawan, untuk menjalankan proyek dan program sosial mereka. AIESEC juga berusaha melakukan 


\section{Vol. 2 No.1 April 2019}

perancangan dan implementasi proyek pengembangan.

\subsubsection{Peran Organisasi Internasional}

Dalam membahas mengenai organisasi internasional, diperlukan pemahaman mengenai peran organisasi tersebut. Oleh karena itu peneliti mencantumkan beberapa teori mengenai peran organisasi internasional menurut para ahli.

Alvin LeRoy Bennet dalam bukunya yang berjudul International Organizations: Principles and Issues berpendapat bahwa organisasi internasional memiliki berbagai peran penting seperti:

1. Menyediakan sarana kerjasama antar negara dalam berbagai bidang, dan kerjasama tersebut memberikan keuntungan bagi sebagian besar ataupun keseluruhan anggotannya. Organisasi Internasional juga menjadi tempat dimana keputusan tentang kerjasama dibuat, dan juga menyediakan perangkat administratif untuk menerjemahkan keputusan tersebut menjadi tindakan.

2. Organisasi Internasional menyediakan berbagai jalur komunikasi antar pemerintah negara, sehingga dapat dieksplorasi dan akan mempermudah akses negara apabila timbul masalah (Bennet \& Oliver, 2002).

Bennett juga menyatakan bahwa peranan organisasi internasional dapat dibagi ke dalam tiga kategori, yaitu:

1. Sebagai legitimasi kolektif bagi aktivitas-aktivitas organisasi dan atau anggota secara individual.

2. Sebagai penentu agenda internasional.

3. Sebagai wadah atau instrument bagi koalisi antar anggota atau koordinasi kebijakan antar pemerintah sebagai mekanisme untuk menentukan karakter dan struktur kekuasaan global (Bennet \& Oliver, 2002)

\subsection{Sustainable Development}

Sustainable Development atau pembangunan keberlanjutan merupakan salah satu kajian hubungan internsional. Konsep ini berkaitan erat dengan maslaah pembangunan di negara berkembang karena banyak negara yang sepakat bahwa negara berkembang merupakan penyumbang kerusakan alam terbesar dan dibutuhkan pembangunan berkelanjutan terutama di negara berkembang. Selain itu, konsep pembangunan berkelanjutan juga erat hubungannya dengan Environtmental Issues karena pembangunan berkelanjutan merupakan salah satu cara untuk mengurangi tingkat kerusakan lingkungan dimasa ini dan dimasa mendatang.

Keberlanjutan adalah konsep yang menggabungkan pesimisme pasca-modern tentang dominasi alam dengan optimisme hampir Pencerahan tentang kemungkinan untuk mereformasi institusi manusia (Dresner, 2002: 164).

Istilah pembangunan berkelanjutan pertama kali dipublikasikan secara luas oleh International Union For The Conservation of Nature In The World Conservation Strategy (1980). Pembangunan Berkelanjutan mencapai kedudukan yang lebih besar setelah laporan seminal yang disiapkan oleh komisi Brundtland. Definisi pembangunan berkelanjutan menurut komisi Brundland adalah pembangunan yang memenuhi kebutuhan masa kini tanpa mengorbankan kemampuan generasi mendatang untuk memenuhi kebutuhan mereka sendiri. konsep keberlanjutan telah lama berakar pada ilmu fisik, biologi, dan teknik (https://onlinelibrary.wiley.com/doi/abs/10.100 2/sd.3460010306 diakses pada 4 Juni 2018).

\subsection{Kerangka Pemikiran}

Hubungan Internasional merupakan hubungan yang terjalin antar negara-negara diseluruh belahan dunia. Setelah berakhirnya Perang Dingin, isu-isu hubungan internasional yang sebelumnya lebih terfokus pada isu-isu high politics (isu politik dan keamanan) meluas ke isu-isu low politics (isu-isu HAM, ekonomi, lingkungan hidup, terorisme). Hubungan internasional kontemporer tidak hanya memperhatikan politik antar negara saja, tetapi juga subjek lain meliputi terorisme, ekonomi, lingkungan hidup, dan lain sebagainya. Selain itu, interaksi tidak hanya dilakukan negara saja, melainkan juga aktor-aktor lain, yaitu, aktor 


\section{Vol. 2 No.1 April 2019}

non-negara juga memiliki peranan yang penting dalam hubungan internasional.

Salah satu aktor yang secara signifikan membantu terjalinnya hubungan antar negara adalah organisasi internasional. Peran dan keberadaan organisasi internasional yang seringkali melibatkan state actors sebagai faktor yang dominan dalam pelaksanaannya. PBB merupakan salah satu organisasi internasional yang memegang peranan penting dalam perjalanan hubungan internasional. PBB seringkali mengeluarkan konvensi-konvensi dan resolusi yang bertujuan untuk menciptakan perdamaian dunia.

Pada bulan September 2015, PBB mengeluarkan resolusi yang berisi capaiancapaian tujuan pembanguann berkelanjutan (SDGs). Terdapat 17 pencapaian didalam SDGs. Setiap negara yang tergabung didalam PBB diwajibkan untuk berusaha mencapai SDGs. Selain aktor negara, berbagai aktor non negara seperti Organisasi Internasional Non Pemerintah hingga aktor individual juga ikut berpartisipasi dalam mencapai SDGs.

AIESEC merupakan organisasi internasional non pemerintah yang ikut berpartisipasi dalam mencapai SDGs. AIESEC merupakan organisasi yang memiliki kantor pusat di Amsterdam, Belanda dan kantor cabang di berbagai negara di dunia, salah satunya Indonesia. Di Indonesia sendiri AIESEC telah bekerja sama dengan 36 universitas di 21 wilayah atau kota.

Berbeda dengan kantor cabang AIESEC di Indonesia, AIESEC di Bandung berkerja sama dengan lebih dari satu universitas. Sebagai kota terbesar ke empat di Indonesia, Bandung memiliki berbagai masalah yang perlu diperbaiki. AIESEC Bandung berusaha membantu kota Bandung dengan berkontribusi mengadakan projek sosial yang fokus di bidang tertentu untuk mengembangkan potensi sumber daya yang lebih baik seperti lingkungan, budaya, dan kewirausahaan dengan mendatangkan lebih dari 120 mahasiswa asing yang datang ke Indonesia.

Sejak bulan Mei 2015 PBB menggandeng AIESEC untuk turut serta mendukung The Global Goals. AIESEC bermitra dengan Kantor
Sekretaris Jenderal Sekretaris Jenderal Perserikatan Bangsa-Bangsa untuk membawa suara pemuda ke dalam percakapan disetiap pertemuan PBB. Oleh karena itu AIESEC membuat proyek-proyek sosial yang berkaitan dengan pencapaian SDGs.

\section{Hasil dan Pembahasan}

\subsection{Program-program AIESEC Bandung dalam Mendukung Pencapaian SDGs}

Sejak awal AIESEC didirikan, kegiatan AIESEC ditingkat lokal terfokus pada kegiatan pertukaran pemuda. Kegiatan ini terbagi atas dua sistem yaitu Incoming dan Outgoing. Incoming merupakan kegiatan dimana para pemuda dari negara lain datang ke sebuah negara untuk melakukan berbagai kegiatan. Dan Outgoing merupakan kegiatan dimana para pemuda dari suatu negara pergi ke negara lain untuk melakukan berbagai kegiatan.

$$
\text { Baik Incoming maupun Outgoing }
$$
terbagai atas tiga kegiatan, yaitu Global Volunteer (GV), Global Talent (GT) dan Global Enterpreuner (GE). GV merupakan kegiatan proyek-proyek sosial dengan yang bertujuan untuk memberikan pengalaman bekerja di challenging environtment kepada pesertanya dan memberikan dampak positif kepada lingkungan tempat proyek tersebut berada. GT dan GV merupakan kegiatan dimana para peserta datang ke suatu negara untuk melakukan kegiatan magang, perbedaannya, pada GT umumnya peserta melakukan kegiatan magang di perusahaan besar dan digaji, sementara pada pada GE peserta melakukan kegiatan magang di start-up atau perusahaan kecil dan tidak digaji.

Setelah AIESEC membuat gerakan Y4GG, perubahan yang paling terasa adalah pada program-program Incoming Global Volunteer (IGV). Setiap kegiatan proyek sosial IGV diharuskan menjadi sejalan setidaknya dengan salah satu tujuan SDGs. Menurut Presiden AIESEC pada tahun 2016-2017, kegiatan proyek sosial AIESEC di Bandung pada tahun 2016 mayoritas sudah ada sejak tahun 2013, namun pada tahun 2016, AIESEC Bandung mengikuti pertintah dari AIESEC Global dengan membuat perubahan pada proyek-proyek tersebut. Tujuan-tujuan SDGS 


\section{Vol. 2 No.1 April 2019}

dimasukan kedalam tujuan setiap proyek sosial. Proyek-proyek sosial AIESEC Bandung pada saat itu adalah:

1. Malala Education Project

Nama proyek ini diambil dari nama Malala Yousafzai, seorang aktivis pendidikan yang berasal dari kota Mingora, Pakistan. Kegiatan utama proyek ini adalah mengajar bahasa Inggris di beberapa tempat di kota Bandung. Umumnya tempat kegiatan proyek ini adalah pesantren, atau rumah singgah. Proyek ini mendukung SDGs Tujuan ke 4 mengenai Quality Education.

2. Sampurasun Culture Project

Sampurasun merupakan sebuah kata sapaan di Bahasa Sunda. Sesuai namanya, proyek ini bertujuan untuk menarik minat pesertanya untuk mempelajari budaya sunda. Proyek ini mendukung SDGs tujuan ke 10 Reduce Inequalities.

\section{Social Enterpreneur Project}

Proyek Social Enterpreneur merupakan proyek yang berfokus untuk membantu pengembangan sebuah desa dengan membantu desa tersebut menambah nilai jual produk desa mereka. Proyek ini mendukung SDGs tujuan ke 8 Decent Work and Economic Growth dan tujuan ke 12 Responsible Consumption and Production

4. I Green Project

Proyek I Green merupakan proyek yang berkaitan dengan perbaikan masalah lingkungan. Kegiatan utama proyek ini adalah membersihkan desa atau suatu lingkungan dan memberi penyadartahuan kepada masyarakat sekitar mengenai waste management, pembuatan kompos, dan sebagainya. Proyek ini berhubungan dengan SDGs tujuan ke 11 Sustainability Cities and Communities.

5. Impacting Love For Cancer Kids Project

Proyek ini merupakan proyek yang berhubungan dengan SDGs tujuan ke 3, Good Health and Well Being. Kegiatan utama proyek ini adalah memotivsi dan mengajar anak kanker di tempat partner AIESEC, dan melakukan penyuluhan kepada orang tua anak kanker mengenai pola makan yang baik untuk anakanak mereka. Selain proyek-proyek diatas, IGV memiliki satu proyek bernama IGV Ad-hoc. Proyek ini merupakan proyek yang sedikit berbeda dengan proyek-proyek lainnya. Kegiatan utama proyek ini adalah mengajar bahasa Inggris. Namun berbeda dengan Malala Project, IGV ad-hoc melakukan kegiatannya di sekolah-sekolah. Selain itu waktu berlangsungnya proyek ini berbeda dengan proyek IGV pada umumnya, melainkan tergantung waktu yang disepakati oleh AIESEC Bandung dan Sekolah partner AIESEC. Kegiatan ini mendukung SDGs ke 4 Quality Education.

Selain IGV, program Global Talent dan Global Enterpreneur yang merupakan program magang juga mendukung SDGs tujuan ke delapan, Decent Work and Economic Growth. Selain itu, sejak tahun 2015 AIESEC Bandung rutin melakukan kegiatan Walk For SDGs (W4SDG). Kegiatan ini merupakan program tahunan AIESEC dimana para anggota AIESEC Bandung beserta anggota beberapa komunitas yang bekerja sama dengan AIESEC melakukan kampanye di tempat publik dalam rangka meningkatkan awareness masyarakat Bandung mengenai SDGs. Kegiatan ini dilakukan serentak di beberapa kota di Indonesia.

Kemudian pada tahun 2017 selain proyekproyek sosial yang sebelumnya dijalankan pada tahun 2016, terdapat perubahan pada Sampurasun Project. Proyek Sampurasun yang awalnya hanya terfokus pada peningkatan minat masyarakat dan pemuda dalam budaya sunda, menjadi upaya Sampurasun dalam menjadikan budaya sunda sebagai tourist attractive dan berganti nama menjadi Sampurasun Culture Enterpreneur Project dan mendukung SDGs tujuan ke 8 mengenai Decent Work and Economic Growth.

AIESEC Bandung juga membuat kerjasama dengan AIESEC di Jerman dan PWC (PricewaterhouseCoopers) sebuah perusahaan yang bergerak dibidang company analyst yang memiliki kantor cabang di Jerman. Kerjasama ini merupakan bagian dari program CSR (Coorporate Social Responsibility) yang dilakukan oleh PWC di tiga negara, yaitu Indonesia, Ghana dan Brazil. Di Indonesia, kegiatan dilaksanakan di Bandung pada tanggal 13 Agustus 2017 hingga 20 September 2017 dengan fokus peningkatan kesadaraan 


\section{Vol. 2 No.1 April 2019}

masyarakat di Bandung, khususnya di desa Maleer mengenai pentingnya waste management, waste separation dan zero waste. Untuk mendukung kegiatan ini, dibuat sebuah proyek sosial I Green x PWC. Menurut salah satu OC dari proyek ini, proyek ini mendapat suntikan dana dari PWC di Jerman, dan peserta kegiatan terdiri atas LV dari Bandung dan EP dari Jerman. Proses perekruitan EP juga tidak dilakukan oleh AIESEC Bandung, namun dilakukan oleh staff PWC karena setiap EP dibiayai oleh PWC. PWC juga mengirimkan satu staff perusahaan untuk memantau jalannya kegiatan.

Selain itu, pada tahun yang sama AIESEC membuat proyek sosial baru yang bernama $I$ Care for Disabled Project. Kegiatan utama ini proyek ini adalah mengajar bahasa inggris di sekolah disabilitas dan memotivasi anak-anak disekolah tersebut. Peserta proyek juga melakukan kegiatan fundraising yang kemudian uangnya dipakai untuk membeli barang-barang yang kemudian diberikan untuk anak-anak yang menjadi murid mereka.

Presiden AIESEC periode 2016-2017 juga berpendapat bahwa AIESEC Global maupun AIESEC Bandung secara keseluruhan juga mendukung SDGs tujuan ke 17 Partnership for the Goal karena AIESEC yang selalu berkerja sama dengan NGO, sekolah dan berbagai partner lain. Selain itu visi AIESEC untuk Strive to Achieve Peace and Fulfilment of Humankind juga sejalan dengan SDGs tujuan ke 16, Peace, Justice and Strong Institutions.

\subsection{Kendala yang dihadapi AIESEC Bandung dalam mendukung pencapaian SDGs \\ 3.2.1 Kesinambungan Proyek Sosial AIESEC Bandung}

Dalam menjalankan setiap kegiatannya AIESEC juga menghadapi berbagai kendala. Pada awal mula AIESEC Bandung membuat proyek-proyek sosial AIESEC relevan dengan tujuan-tujuan SDGs mereka juga memasukan target-target tujuan SDGs yang relevan dengan proyek tersebut untuk menajdi tujuan proyek tersebut.

Namun, seiring berjalannya waktu dan pergantian pengurus di AIESEC yang berlangsung cepat membuat seringnya terjadi miss-communication antar anggota. Proyekproyek sosial AIESEC Bandung sejak tahun 2017 hanya terfokus pada tujuan SDGs yang align dengan project tersebut tanpa melihat target SDGs mana yang harus mereka capai.

Permasalahan lain datang dari peserta proyek sosial AIESEC. Setiap proyek sosial IGV dijalankan oleh Organizing Comittee (OC), Exchange Participants (EP) dan Local Volunteer (LV). Sesuai dengan masa berjalan proyek yang hanya 6 minggu, EP dan LV juga bekerja selama 6 minggu. Namun OC selaku penyelenggara project bekerja selama kurang lebih 2 bulan sebelum proyek dimulai untuk mempersiapkan proyek dan satu bulan setelah proyek berlangsung untuk mengevaluasi hasil kegiatan. Umumnya OC setiap proyek berbeda dengan proyek sebelumnya dan proyek di gelombang selanjutnya. Sehingga para EB harus mengulang kembali penjelasan mengenai proyek-proyek dan SDGs kepada para OC yang baru menjabat.

Pergantian OC yang terjadi setiap sebuah proyek selesai menyebabkan kurang paham nya para OC baru mengenai isu-isu SDGs dan keuntungan proyek tersebut untuk mereka dan kota Bandung. Selain itu tidak ada jaminan bahwa setelah proyek selesai para peserta proyek akan terus melakukan hal-hal positif yang dilakukan selama proyek berlangsung. Contohnya partisipan proyek I Green meskipun selama proyek para pesertanya baik OC, EP maupun LV tidak membuang sampah sembarangan, melakukan kegiatan memungut sampah dan melakukan reduce, reuse, recycle, tidak ada jaminan bahwa mereka akan terus melakukan hal-hal tersebut setelah proyek berakhir.

Pergantian OC yang begitu cepat juga seringkali menyebabkan perbedaan kualitas suatu proyek. Pemilik Rumah Cinta Anak Kanker (RCAK) salah satu partner proyek Impacting Love for Cancer Kids Bandung, menyatakan bahwa AIESEC Bandung telah berkerja sama dengan RCAK lebih dari satu kali. Terakhir kali AIESEC Bandung melakukan kegiatan di RCAK adalah bulan Juli hingga Agustus 2017. Pemilik RCAK beranggapan proyek tersebut kurang baik dan tidak seperti 
Vol. 2 No.1 April 2019

kegiatan AIESEC sebelumnya. Peserta proyek cenderung cuek dan tidak menunjukan kedekatan dengan anak-anak kanker di RCAK.

\subsubsection{Kesulitan Mencari Partner}

Masalah lain dalam menjalankan proyek sosial di IGV AIESEC Bandung adalah sulitnya mencari partner baru. Dalam rangka memperluas jangkauan AIESEC, biasanya proyek-proyek sosial AIESEC mencari partner baru untuk digandeng di proyek yang akan dilaksanakan.

Menurut OC Partnership proyek Social Enterpreneurship periode winter 2016, seringkali calon partner yang didatangi oleh proyek-proyek AIESEC menolak berkerja sama karena posisi AIESEC sebagai INGO yang tidak bisa memberikan keuntungan berupa materi kepada partner. Seringkali meskipun partner sudah sepakat berkerja sama dan menandatangani Memo of Understanding (MoU) namun ditengah-tengah kegiatan proyek partner tersebut memutuskan kerjasama secara sepihak. Pada saat hal tersebut terjadi, setiap OC Partnership harus mencari partner baru dan tidak bisa menuntut partner sebelumnya karena tidak adanya pasal yang memberatkan partner apabila mereka memutuskan hubungan secara sepihak di MoU yang ada.

Selain dalam pelaksanaan proyek sosial di IGV, kegiatan W4SDG juga memiliki beberapa kendala. Kegiatan ini bertujuan untuk meningkatkan awareness masyarakat Bandung mengenai SDGs. Selama dua tahun, tahun 2016 dan 2017, kegiatan W4SDG diadakan di wilayah Car Free Day Dago, Bandung. AIESEC mengundang beberapa komunitas di Bandung, seperti Warung Imajinasi dan StudentxCEO. Kekurangan dari kegiatan ini adalah kurangya peserta kampanye sehingga masyarakat tidak tertarik untuk mendengarkan materi kampanye.

\subsubsection{Kerjasama Dengan Pemerintah}

Menurut kepala di Office of the United Nations Resident Coordinator di Indonesia, sebagus apapun kegiatan sebuah komunitas maupun organisasi, akan lebih baik apabila kegiatan-kegiatan tersebut juga bersinergi dengan upaya pemerintah dalam mencapai tujuan-tujuan SDGs diwilayah tersebut. Karena pemerintah negara tersebut lah yang nantinya akan mengirim laporan perkembangan SDGs dinegara tersebut. Bisa saja suatu organisasi membuat perkembangan yang signifikan dalam mencapai SDGs dinegara disuatu negara namun karena kurangnya komunikasi antar organisasi dan pemerintah, pemerintah tidak mengakui adanya peran organisasi tersebut.

Sayangnya, kegiatan proyek sosial AIESEC umumnya dibuat berdasarkan hasil survey Youth Speak Forum yang merupakan forum internal AIESEC. Bukan berdasarkan Rencana Pembangunan Jawa Barat. Sehingga belum tentu hasil survey tersebut segaris dengan program pemerintah. Presiden AIESEC periode 2017-2018 menyatakan bahwa AIESEC sempat beberapa kali berusaha bekerja sama dengan pemerintah. Namun hingga saat ini baru satu proyek yang terealisasikan, yaitu proyek IGV Si Windu Malala dan Si Windu Social Enterpreneur dan kegiatan magang GE Si Windu.

Kedua proyek ini sudah dirancang sejak tahun 2017 namun pelaksanannya terjadi pada bulan Juli hingga Agustus 2018. Untuk proyek IGV Si Windu, SDGs yang didukung oleh proyek ini adalah SDGs tujuan ke 4 Quality Education karena kegiatan utama proyek ini adalah mengajar bahasa inggris. Sementara untuk program GE Si Windu, AIESEC bekerja sama dengan pemerintah kota Kuningan dalam menjadikan Kuningan sebagai obyek wisata di Jawa Barat. Terdapat beberapa pekerjaan untuk peserta kegiatan magang ini, yaitu, Tourist Development, Trip Organizer Officer, Content Marketing, Graphic Designer, Public Relation dan Videographer

\subsection{Pencapaian AIESEC Bandung dalam mendukung tercapainya SDGs}

Berdasarkan hasil penelitian dan observasi peneliti, kegiatan AIESEC baik IGV, GT dan GE memiliki dampak yang bagus dalam mendukung SDGs. Karena dampak dari kegiatan-kegiatan tersebut tidak hanya dirasakan oleh peserta kegiatan namun juga oleh masyarakat sekitar proyek tersebut diadakan.

Untuk melihat objektifitas kegiatan AIESEC Bandung, peneliti mewawancarai 


\section{Vol. 2 No.1 April 2019}

beberapa peserta kegiatan AIESEC Bandung. Yang pertama, salah satu peserta proyek yang berasal dari Pakistan yang mengikuti kegiatan proyek Sampurasun Culture Project pada bulan Juni hingga Juli 2017. Ia mengatakan bahwa proyek yang ia ikuti memberikan banyak pengetahuan mengenai budaya Sunda. Semua partisipan proyek tersebut berusaha untuk mengajak lebih banyak masyarakat Bandung untuk mengenal dan menyukai budaya Sunda. Namun akan lebih baik bila peserta proyek bisa berinteraksi lebih dengan para pemuda di Kota Bandung, karena sepanjang proyek berlangsung para peserta lebih sering dipertemukan dengan orang-orang yang sudah ahli dibidang budaya Sunda. Selain itu selama proyek berlangsung beberapa kali terjadi miscommunication dengan partner proyek sehingga selama beberapa hari peserta kegiatan tidak melakukan apapun. Meski begitu ia beranggapan bahwa kegiatan ini membantunya dalam mengenal global unity dengan lebih baik.

Peserta kedua yang peneliti wawancara adalah perserta proyek Social Enterpreneurship periode bulan Desember 2016 hingga Januari 2017 yang berasal dari India. Ia merasa bahwa proyek Social Enterpreneur memberikan dampak besar baginya. Ia juga mendapatkan pengetahuan mengenai SDGs secara lebih kompleks setelah bergabung dengan proyek tersebut membantu pengusaha-pengusaha yang didatangi selama proyek berlangsung dalam mengembangkan bisnis menggunakan teknologi dan inovasi. Ia juga merasa bahwa kegiatan tersebut merasa termotivasi dan terinspirasi untuk kembali ke India dan membantu masyarakat sekitar. Setelah kembali dari Bandung, peserta proyek ini menawarkan konsultasi secara gratis bagi wirausahawan di daerah tempat tinggalnya untuk membantu mereka mengembangkan usaha mereka, dan menjadi sukarelawan disebuah panti asuhan untuk perempuan.

Selain mewawancarai peserta proyek sosial AIESEC Bandung, peneliti jug mewawancarai salah satu partner proyek Malala, Rumah Baca Lentera. Pemilik Rumah Baca Lentera menyatakan bahwa proyek Malala membuat anak-anak di Rumah Baca Lentera lebih tertarik untuk belajar, terutama belajar bahasa Inggris. Lebih dari itu, anak-anak disana menjadi lebih berani untuk mengungkapkan pendapatnya dan menjadi lebih percaya diri. Para staff pengajar baik EP dan LV bisa melakukan pendekatan dengan anak-anak dalam waktu yang relatif cepat.

Salah satu proyek AIESEC Bandung, Impacting Project sempat dipublikasikan di salah satu media online, Tribun Jabar. Impacting merupakan proyek sosial dimana para EP dan LV melakukan observasi terhadap anak-anak kanker di rumah kanker yang menjadi partner mereka. Mereka mencari tahu hal-hal yang dapat meningkatkan motivasi hidup anak-anak. Setelah itu para peserta proyek mengajar bahasa inggris dan melakukan sharing budaya negara asal para EP. Mereka juga membantu para pengurus rumah kanker dalam merawat anakanak kanker di rumah tersebut. Para peserta proyek juga memberikan presentasi di beberapa sekolah di Kota Bandung mengenai pola hidup sehat dan pencegahan kanker. Proyek ini selama beberapa periode berkerja sama dengan Yayasan Kasih Anak Kanker Indonesia (YKAKI) dan Rumah Cinta Anak Kanker (RCAK). Anak-anak yang tinggal di kedua tempat tersebut umumnya adalah anak-anak yang menderita kanker dan berasal dari luar kota Bandung, dan tidak mampu menyewa tempat tinggal selama masa pengobatan di kota Bandung (Hasil wawancara dengan Organizing Committee Impacting Project summer tahun 2017).

Kegiatan AIESEC yang terus berlangsung setiap tahun membuat proyek-proyek AIESEC menjadi sustainable. Kegiatan ini juga selalu meninggalkan suatu hasil, contohnya pada proyek Social Enterpreneur, setiap desa atau wilayah yang menjadi lokasi proyek sosial AIESEC selalu memiliki produk untuk kemudian dikembangkan, atau produk mereka yang awalnya kurang menarik menjadi lebih menarik baik itu produknya maupun packagingnya.

Contoh lain datang dari proyek I Green, dimana para sukarelawan melakukan kegiatan bersih-bersih di desa atau daerah yang berkerja sama dengan proyek tersebut. Selain itu para sukarelawan juga dilatih untuk melakukan waste 
Vol. 2 No.1 April 2019

management untuk kemudian diimplementasikan di daerah kegiatan proyek. Para peserta proyek juga melakukan presentasi mengenai pentingnya waste management dan perilaku perduli lingkungan kepada masyarakat sekitar dan sekolah-sekolah setempat. (Hasil wawancara dengan Organizing Committee I green Project Summer tahun 2017)

Diakhir kegiatan proyek, umumnya akan diadakan kegiatan fundraising dan uang dari kegiatan tersebut akan digunakan untuk membeli barang-barang yang dibutuhkan oleh lokasi kegiatan proyek, contohnya untuk proyek Malala, uang hasil fundraising digunakan untuk membeli buku dan barang edukasi lain untuk disumbangkan ke partner proyek.

\subsection{Analisis Peran AIESEC Bandung dalam Mendukung Pencapaian SDGs}

Berdasarkan hasil penelitian diatas, apabila melihat teori Mostashari (2005), AIESEC Bandung dapat dikategorikan sebagai NGO Operasional, karena AIESEC berkerja dengan cara menggerakan sumber daya dalam bentuk relawan, dan memiliki kantor pusat dinegara maju yaitu Belanda, namun beroperasi di lebih dari satu negara berkembang. Tidak hanya itu, berdasarkan hasil wawancara dengan Vice President (VP) Finance AIESEC di Bandung periode 2018-2019, AIESEC Bandung memperoleh dana untuk menjalankan setiap kegiatannya dari para anggota dan sponsor AIESEC di Bandung.

Hal ini dilakukan berdasarkan hasil rapat tingkat nasional di berbagai negara yang dihadiri oleh setiap Local Committee President (LCP) AIESEC di berbagai wilayah dan kota. Setiap LC AIESEC melegislasi hal ini. Dengan ini setiap kantor AIESEC harus mengirimkan National Fee ke kantor AIESEC di tingkat Nasional di negara tersebut. Kantor AIESEC di tingkat nasional juga harus mengirimkan uang kepada kantor AIESEC di tingkat Global. Pada AIESEC LC di Bandung, umumnya partisipan yang ingin mengikuti kegiatan AIESEC di luar negeri harus membayar uang pendaftaran sebesar 2 juta hingga tiga juta rupiah, dan untuk peserta yang ingin menjadi sukarelawan di kota Bandung membayar seratus lima puluh ribu rupiah. Sementara peserta asing yang ingin mengikuti kegiatan AIESEC di Bandung harus membayar sekitar $\$ 45$ per orang. Dalam satu tahun, AIESEC Bandung bisa mendapatkan dana sekitar 450 juta. Dana tersebut digunakan untuk menjalankan setiap kegiatan AIESEC di Bandung, membayar uang sewa rumah yang dijadikan Kantor oleh AIESEC di Bandung, dan untuk membayar National Fee. Di tingkat Nasional, selain mendapatkan dana dari setiap entitas AIESEC di Indonesia, AIESEC di Indonesia juga mendapatkan dana dari peserta kegiatan National Conference yang diadakan empat kali dalam setahun. Dana yang terkumpul digunakan untuk membiayai kegiatan AIESEC di tingkat nasional, dikirimkan ke AIESEC Global dan untuk membayar keperluan legalitas AIESEC di Indonesia (Hasil wawancara dengan VP Finance AIESEC di Bandung periode 20182019).

Melihat dari kegiatan AIESEC di Bandung yang berusaha untuk membangun wilayah sekitar lokasi kegiatan, baik membangun minat masyarakat terhadap suatu isu, maupun meningkatkan kesadaran masyarakat terhadap suatu isu, maka AIESEC Bandung dapat dikategorikan sebagai NGO dengan orientasi High Level Partnership: Grassroots Development berdasarkan teori Elderidge yang dikutip dalam buku Tadjoedin Zulfan yang berjudul Explaining Collective Violence in Comtemporary Indonesia: From Conflict to Cooperation (2008). Orientasi ini ditandai dengan hubungan anggota yang sangat partisipatif, mengutamakan kegiatan yang berkaitan dengan pembangunan dibanding dengan kegiatan yang bersifat advokasi, kurang memiliki minat pada hal yang bersifat politis, namun mempunyai perhatian yang besar untuk mempengaruhi kebijakan pemerintah dengan selalu memelihara dukungan pada tingkat dasar.

Selanjutnya, Clive Archer dalam buku International Organization - 3rd Edition menyatakan beberapa peranan organisasi internasional, yang pertama organisasi internasional berperan sebagai instrumen, maksudnya organisasi internasional dipakai oleh anggotanya untuk mencapai tujuan tertentu, biasanya terjadi pada IGO dimana negara 


\section{Vol. 2 No.1 April 2019}

berdaulat merupakan anggotanya yang dapat membatasi tindakan organisasi internasional. Organisasi penting bagi pencapaian kebijakan nasional yang mana koordinasi multilateral tetap menjadi sasaran dan tujuan jangka panjang pemerintah nasional.

Melihat pada teori tersebut, AIESEC merupakan wadah bagi para anggotanya untuk mencapai tujuan mereka, dan meskipun AIESEC merupakan organisasi independen yang tidak bergantung pada pemerintah, AIESEC tetap membutuhkan bantuan pemerintah untuk bisa berada di Indonesia. AIESEC juga berperan dalam membantu pemerintah mencapai tujuan jangka panjang panjang pemerintah dibidang peningkatan tujuan-tujuan yang tercapai di SDGs. Meskipun kontribusi yang diberikan AIESEC tidak begitu besar, namun kegiatan yang dilakukan setiap bulan di setiap tahun sudah pasti akan memberikan dampak yang berarti.

Archer juga menyatakan bahwa organisasi internasional juga berperan sebagai arena atau forum, dalam organisasi internasional terjadi aksi-aksi yang dilakukan oleh anggotanya yakni sebagai tempat pertemuan untuk berkumpul bersama-sama baik itu berupa berdiskusi, berdebat, ataupun bekerjasama. Organisasi internasional juga menyediakan kesempatan bagi anggotanya untuk lebih meningkatkan pandangan atau opininya dalam suatu forum publik.

Dalam hal ini, AIESEC merupakan tempat berdiskusi, berdebat, ataupun bekerjasama para anggotanya. Karena dalam menjalankan sebuah proyek sosial, tidak mungkin setiap anggotanya tidak mendiskusikan kegiatan mereka. Terlebih lagi, peserta proyek yang berasal dari berbagai negara yang berbeda dengan latar belakang yang berbeda pasti memiliki pemikiran yang berbeda-beda pula.

Sebagai aktor yang independen, dalam melaksanakan fungsi dan perannya, organisasi internasional dapat bertindak sesuai dengan kewenangan yang ada tanpa dipengaruhi oleh pihak-pihak atau kekuatan dari luar yang dapat dipergunakan oleh mereka sebagai alat untuk memenuhi kepentingan mereka.
AIESEC sebagai organisasi internasional dapat melakukan kegiatannya dengan leluasa. Pada tahun 2016 pemerintah Indonesia belum melakukan upaya yang berarti untuk mendukung SDGs dan bahkan pemerintah Indonesia baru membuat peraturan pemerintah mengenai SDGs pada tahun 2017, namun AIESEC Bandung sudah terlebih dulu membuat proyek-proyek sosial yang relevan dengan pencapaian SDGs dan sudah mengimplementasikannya.

Dapat disimpulkan bahwa peranan AIESEC di Bandung sebagai INGO dalam mendukung SDGs meskipun kontribusinya tidak terlalu besar, namun AIESEC Bandung sudah memulai upayanya dalam mendukung SDGs sejak awal SDGs dicetuskan. Kegiatan AIESEC yang selalu melibatkan berbagai pihak juga membantu peningkatan kesadaran masyarakat terutama partner-partner dan anggota AIESEC mengenai pentingnya

SDGs.

\section{Kesimpulan dan Saran \\ 4.1 Kesimpulan}

AIESEC adalah organisasi pemuda global, independen, non pemerintah dan nirlaba yang didirikan pada tahun 1948 oleh sekelompok orang muda Eropa yang berasal dari negaranegara yang berbeda.

Jawaban atas pertanyaan langkah-langkah yang dilakukan AIESEC Bandung dalama mendukung pencapaian SDGs dimulai setelah diluncurkannya SDGs, pada bulan Desember 2015, para ketua AIESEC dan perwakilanperwakilan AIESEC yang berasal dari 126 negara berkumpul di United Nations Headquarters utnuk mempromosikan dan mendorong para orang muda untuk berpartisiasi dalam proses implementasi SDGs. AIESEC Global yang pada masa itu diketuai oleh Ana Saldariaga kemudian berinisiatif membuat gerakan Youth 4 Global Goals (Y4GG) yang bertujuan menggerakkan para pemuda dalam mengimplementasikan SDGs.

Setelah AIESEC membuat gerakan Y4GG, setiap kegiatan AIESEC terutama proyek-proyek sosial AIESEC harus menjadi relevan dengan setidaknya salah satu tujuan SDGs. Kegiatan proyek sosial AIESEC di Bandung pada tahun 2016 mayoritas sudah ada 


\section{Vol. 2 No.1 April 2019}

sejak tahun 2013, namun dengan adanya program Y4GG AIESEC Bandung membuat perubahan pada proyek-proyek tersebut.

Program GE dan GT sudah secara jelas mendukung SDGs tujuan ke 8 Decent Work and Economic Growth. Kemudian Executive Board (EB) dan staff di AIESEC Bandung menambah tujuan proyek-proyek sosial di AIESEC Bandung untuk menjadi relevan dengan setidaknya salah satu tujuan SDGs. Hasil penambahan tujuan SDGs pada proyek-proyek sosial AIESEC Bandung adalah proyek edukasi Malala yang mendukung SDGs tujuan ke 4 Quality Education, proyek budaya Sampurasun yang mendukung SDGs tujuan ke 10 Reduce Inequalities, proyek Social Enterpreneur yang mendukung SDGs tujuan ke 8 Decent Work and Economic Growth, proyek I Green yang mendukung SDGs tujuan ke 11 Sustainable Cities and Communities, proyek I Care for Disabilities yang mendung SDGs tujuan ke 4 Quality Education, proyek Impacting Love for Cancer Kids yang mendukung SDGs tujuan ke 3 Good Health and Well Being dan proyek-proyek GV Ad-hoc yang mendukung SDGs tujuan ke 4 Quality Education.

Kegiatan proyek sosial AIESEC mendapat respon positif dari banyak sukarelawan dan partner kegiatan, terbukti dengan proyek sosial AIESEC yang terus terjadi selama bertahuntahun. Meski begitu, terdapat beberapa kendala dalam menjalankan proyek, yang pertama adalah sulitnya mempertahankan kesinambungan proyek. Hal tersebut disebabkan oleh beberapa alasan, yaitu adanya miscommunication antara EB AIESEC Bandung pada tahun 2016 dan penerusnya, sehingga proyek-proyek sejak tahun 2017 hanya terfokus pada pencapaian tujuan SDGs tanpa melihat target SDGs yang harus dicapai. Ditambah dengan pergantian Organizing Committee (OC) yang berlangsung setiap dua periode dalam satu tahun, menyebabkan kurang terintegrasinya satu proyek dan proyek selanjutnya. Banyak OC yang tidak paham mengenai isu-isu SDGs, keuntungan proyek tersebut untuk mereka dan kota Bandung. Akibatnya kualitas proyek setiap periode berbeda-beda.
Kendala lain adalah sulitnya mencari partner. Sebagai INGO yang dijalankan oleh pemuda, AIESEC seringkali harus bergantung pada partner. Dan untuk memperluas jangkauan proyek sosial AIESEC Bandung, setiap periode AIESEC Bandung seringkali mencari partner baru untuk proyek sosial mereka. Namun tidak sedikit calon partner yang menolak bekerja sama dengan AIESEC Bandung, dan umumnya hal tersebut dikarenakan AIESEC tidak dapat memberikan keuntungan berupa materi kepada partner.

Kendala lain adalah tidak adanya kerjasama antara AIESEC Bandung dan Pemerintah. Meskipun AIESEC merupakan organisasi independen dan non-politik, namun untuk memaksimalkan pencapaian SDGs dibutuhkan peran pemerintah. Selain itu proyekproyek sosial AIESEC Bandung yang dibuat berdasarkan keluhan-keluhan pemuda pada survey YouthSpeak Forum belum tentu sejalan dengan rencana pembangunan pemerintah. Meskipun proyek sosial AIESEC Bandung memberikan dampak positif pada pencapaian SDGs, namun perubahan yang diberikan oleh AIESEC akan lebih besar apabila proyek-proyek AIESEC Bandung bisa tepat sasaran.

Dibalik setiap kendala yang dihadapi oleh AIESEC Bandung, kegiatan AIESEC yang terus berlangsung setiap tahunnya merupakan sebuah pencapaian. Setiap proyek yang dibuat oleh AIESEC Bandung meninggalkan hasil positif baik bagi peserta atau sukarelawan proyek, namun juga untuk partner proyek dan lingkungan tempat kegiatan proyek berlangsung.

Adapun pencapaian yang sudah dicapai oleh AIESEC Bandung baik IGV, GT dan GE memiliki dampak yang bagus dalam mendukung SDGs. Karena dampak dari kegiatan-kegiatan tersebut tidak hanya dirasakan oleh peserta kegiatan namun juga oleh masyarakat sekitar proyek tersebut diadakan. Berdasarkan wawancara dengan berbagai narasumber, dapat dilihat bahwa baik peserta proyek maupun partner proyek merasakan manfaat. Peserta proyek mendapatkan pengalaman membantu memperbaiki permasalahan di lokasi proyek, dan partner proyek terbantu dengan adanya proyek-proyek AIESEC Bandung. 


\subsection{Saran}

Setelah melihat hasil penelitian ini, maka saran yang diberikan oleh peneliti terhadap organisasi AIESEC LC Bandung dalam mendukung mendukung pencapaian SDGs adalah mempertahankan kegiatan-kegiatan AIESEC Bandung karena sejauh ini kegiatankegiatan AIESEC Bandung sudah berperan baik dalam meningkatkan kesadaran masyarakat dan anggota AIESEC Bandung mengenai pentingnya SDGs, serta membantu pencapaian SDGs disekitar lokasi kegiatan.

Meski begitu, akan lebih baik apabila AIESEC meninjau ulang sistem pergantian OC yang terjadi setiap periode. Akan lebih baik apabila pada proyek selanjutnya, setidaknya ada satu atau dua OC yang sebelumnya berkerja pada proyek yang sama untuk memastikan keberlanjutan proyek tersebut dan untuk mengedukasi OC-OC yang baru terlibat dengan proyek tersebut. Peneliti juga berharap AIESEC Bandung memastikan tidak hanya tujuan besar SDGs yang berkaitan dengan proyek sosial namun juga target-target capaian didalam tujuan SDGs tersebut sebagaimana EB AIESEC Bandung pertama kali membuat proyek-proyek sosial AIESEC Bandung relevan dengan tujuan dan target SDGs.

Selain itu, kesulitan AIESEC dalam mencari partner baru bisa jadi disebabkan oleh tidak adanya sinergi antara AIESEC Bandung dan pemerintah setempat oleh karena itu AIESEC sebaiknya menggandeng badan pemerintah yang relevan dengan proyek sosial AIESEC, misalnya untuk proyek Sampurasun yang bergerak di bidang budaya, AIESEC Bandung bisa menggandeng Dinas Kebudayaan dan Pariwisata Kota Bandung, atau Dinas Pariwisata dan Kebudayaan Provinsi Jawa Barat.

Saran peneliti untuk penelitian yang selanjutnya adalah akan lebih baik apabila peneliti selanjutnya mencari data lebih dalam mengenai Rancangan Pembangunan Jangka Menengah (RPJM) pemerintah Jawa Barat dan melihat program-program pemerintah yang relevan dengan proyek-proyek sosial AIESEC untuk membantu AIESEC dalam bersinergi dengan pemerintah. Dan secara metodologis dalam hal pengumpulan data diperlukan pengembangan data yang lebih mendalam mengenai kegiatan proyek-proyek sosial AIESEC dan juga kegiatan GE dan GT AIESEC Bandung, serta pandangan lebih banyak anggota dan partner AIESEC Bandung mengenai peran AIESEC Bandung. Dengan melengkapi datadata melalui dokumen RPJM pemerintah maka penggambaran mengenai kegiatan upaya AIESEC dalam mendukung pencapaian SDGs dapat disajikan dengan lebih baik, hal tersebut tidak dapat dilakukan dalam penelitian ini karena adanya beberapa hambatan lain yang harus dihadapi peneliti.

\section{Daftar Pustaka}

\section{Acuan dari Buku}

Archer, Clive. 2001. International Organization - 3rd Edition. London: Routledge

Bennett, Alvin LeRoy dan James K. Oliver. 2002. International organizations: principles and issues. Englewood Cliffs, N.J. : Prentice Hall

Dresner, Simon. 2002. The Principles of Sustainability. London: Earthscan Publications Ltd

Dugis, Vinsensio. 2016. Teori Hubungan Internasional Perspekif-Perspektif Klasik. Surabaya: Cakra Studi Global Strategis (CSGS)

Jemadu, Aleksius. 2008. Politik Global Dalam Teori dan Praktek, Yogyakarta, Graha Ilmu

Ririen, Astria. 2009. Kinerja NGO. Jakarta: PT Rineka Cipta

\section{Acuan dari Dokumen dan Jurnal}

AIESEC. 2016. AIESEC Blue Book Brand Toolkit.

AIESEC. 2015. The AIESEC Way.

Triwahyuni, Dewi. 2010. Pendirian Dan

Pembubaran Organisasi Internasional.

Universitas Komputer Indonesia:

Bandung

\section{Acuan dari Rujukan Elektronik}

Steer, Andrew dan Will Wade-Gery. 1993. Sustaibale Development: Theory and Practice for a Sustainable Future. Melalui 
Vol. 2 No.1 April 2019

https://onlinelibrary.wiley.com/doi/abs/10

$.1002 /$ sd.3460010306 diakses pada 4 Juni 2018

The Guardian. 2015. Sustainable Development Goals United Nations. https://www.theguardian.com/globaldevel opment/2015/jan/19/sustainabledevelopm ent-goals-united-nations diakses pada 4 Januari 2018

The

United

Nations.

legal.un.org/avl/ha/vcltsio/vcltsio.html diakses pada 3 April 2018

UPI. 2015. Muda Potensial dan Berpengaruh. berita.upi.edu/muda-potensial-danberpengaruh/ diakses pada 14 April 2018 